\title{
PELAKSANAAN UNDANG-UNDANG NOMOR 15 TAHUN 2014 DALAM PENETAPAN LABUNGKARI SEBAGAI IBUKOTA KABUPATEN BUTONTENGAH
}

\author{
OLEH : \\ DARMAWAN WIRIDIN \\ DOSEN FAKULTAS HUKUM \\ UNIVERSITAS DAYANU IKHSANUDDIN
}

\begin{abstract}
The Law's Observation Of Regulation Number 15th 2014 Related With The Establishment Of Labungkari as The Capital City Of Middle Buton Districk..The aim of this research is to find out the advisability of Labungkari as the Capital City of Middle Buton Districk observed from a law's side and to find out a background, a weakness, and surplus of established Labungkari as the Capital City of Middle Buton Districk. This research was done in Labungkari, exactly in a government of Middle Button Districk.The method was applied in this research is the descriptive method and purposed to describe anything that have forms the background of establishment Labungkari as the Capital City Of Middle Buton Districk. The writer use a qualitative analysis based on a reports and a documentation in the field. A data collecting technique in this research includes by a profound interview and a secondary data and a tertiary data a study book, a document, and the articles.From the research, the writer concluded that the establishment Labungkari as the Capital City of Middle BurtonDistrict is not advisable because the establishment is not based on a mechanism that have permanently in a law and the establishment is just based on a collective consensus between a societies element.
\end{abstract}

Keyword : Region Establishment, Requirement Of Establishment Region.

\section{A. PENDAHULUAN}

Dalam penyelenggaraanpemerintahan didaerah diberikan otonomi yang lebih luas dan lebih nyata kepada pemerintah daerah untukmenyelenggarakan urusan rumah tangganya sendiri. Hal ini dimungkinkan sebagai konsekuensi kebijakan desentralisasi yang dianut dalam Undang-Undang Nomor 23 Tahun 2014 tentang Pemerintahan Daerah. Perlu dibentuk daerah-daerah otonomi dalam wilayah NegaraKesatuan Republik Indonesia. Hal ini sejalan dengan ketentuan pasal 18 ayat (1),(2) Undang-Undang Dasar Negara Republik Indonesia Tahun 1945.

Semangat otonomi daerah dan fenomena keinginan masyarakat pada berbagai wilayah untuk membentuk daerah otonomi baru yang terjadi dihampir seluruh daerah dinegara ini juga terasa pada masyarakat Buton. Masyarakat Buton yang menghendaki daerah Kabupaten Buton dimekarkan lagi menjadi dua daerah otonomi baru yang salah satunya adalah Kabupaten Buton Tengah. Tuntutan masyarakat yang sangat kuat 
ditingkat bawah (grassroot) tersebut didorong oleh keinginan memperoleh pelayanan yang baik dari Pemerintah Daerah.

Dalam pembentukan Daerah Otonomi Baru harus memenuhi syarat fisik kewilayahan yang meliputi persyaratan dasar kewilayahan dan persyaratan dasar kapasitas daerah. Syarat fisik kewilayahan ini meliputi cakupan wilayah, lokasi calon ibukota kabupaten, sarana dan prasarana pemerintahan. Penetapan lokasi ibukota tersebut dilakukan setelah adanya kajian daerah terhadap aspek tata ruang, ketersediaan fasilitas, aksestabilitas, kondisi dan letak geografis, kependudukan, sosial ekonomi, sosial politik dan sosial budaya. Adanya sarana dan prasarana pemerintahan meliputi bangunan dan lahan untuk kantor kepala daerah, kantor DPRD, dan kantor perangkat Daerah yang dapat digunakan untuk memberikan pelayanan kepada masyarakat. Bangunan dan lahan berada dalam wilayah calon daerah serta lahan dimiliki pemerintah daerah dengan bukti kepemilikan yang sah.

Kabupaten Buton Tengah menjadi daerah otonomi baru yang sebelumnya masuk dalam cakupan wilayah Kabupaten Buton. Hal ini bertujuan untuk mendorong perkembangan dan kemajuan provinsi Sulawesi Tenggara pada umumnya dan Kabupaten Buton pada khususnya. Adanya aspirasi yang berkembang dalam masyarakat juga dipandang perlu, untuk meningkatkan penyelenggaraan pemerintahan, pembangunan dan pelayanan publik sehingga mempercepat terwujudnya kesejahteraan masyarakat. Dalam Undang-Undang Nomor 15 Tahun 2014 tentang pembentukan Buton Tengah ditetapkan Labungkari sebagai ibukotanya. Sebelum adanya pemekaran ini ada beberapa wilayah yang diusulkan untuk menjadi ibukota kabupaten, diantaranya Wamengkoli, Lakudo dan Mawasangka. Dalam hal ini Labungkari tidak masuk dalam pengusulan calon Ibukota Kabupaten Buton Tengah.

\section{B. TINJAUAN PUSTAKA}

\section{a. Otonomi Daerah}

Otonomi daerah berasal dari bahasa yunani "autonomie" yang berarti auto adalah sendiri dan nomos adalah Undang-Undang. Jadi secara harfiah otonomi dapat diartikan sebagai pemberian hak dan kekuasaan untuk mengatur dan mengurus rumah tangganya sendiri kepada instansi, perusahaan dan daerah. 
Menurut Bagir Manan Otonomi Daerah mempunyai dua arti, pertama dalam arti formal otonomi daerah diperlukan dalam rangka memperluas partisipasi masyarakat dalam pemerintahan, kedua dalam arti materiil otonomi daerah mengandung makna sebagai usaha mewujudkan kesejahteraan yang bersanding dengan prinsip negara kesejahteraan dan sistem pemencaran kekuasaan menurut dasar negara berdasarkan atas hukum. Sedangkan menurutJoko Widodo, pada hakekatnya otonomi daerah bertujuan menciptakan sebuah sistem pemerintahan yang lebih demokratis, dimana keterlibatan rakyat baik dalam penyelenggaraan pemerintahan, pembangunan dan pelayanan publik maupun dalam melakukan kontrol atas apa yang sedang dan dilakukan pemerintah dalam menjalankan tugas pokok, fungsi dan kewenangan dapat dilaksanakan secara maksimal. Oleh karena itu dengan otonomi daerah diharapkan akan dapat memberi peluang pada perubahan kehidupan pemerintah daerah.

Pengertian daerah otonom menurut UU No. 23 Tahun 2014, “Daerah otonom selanjutnya disebut daerah adalah kesatuan masyarakat hukum yang mempunyai batasbatas wilayah yang berwenang mengatur dan mengurus urusan pemerintahan dan kepentingan masyarakat setempat menurut prakarsa sendiri berdasarkan aspirasi masyarakat dan sistem Negara Kesatuan Republik Indonesia". Prinsip otonomi daerah yang digunakan berdasarkan ketentuan Undang-Undang Nomor 23 Tahun 2014 yang menekankan pada perwujudan otonomi yang seluas-luasnya nyata dan bertanggung jawab.

Prinsip otonomi seluas-luasnya dalam arti daerah diberikan kewenangan mengurus dan mengatur semua urusan pemerintahan diluar yang menjadi urusan pemerintah. Daerah memiliki kewenangan membuat kebijakan daerah untuk member pelayanan, peningkatan, peran serta, prakarsa dan pemberdayaan masyarakat yang bertujuan pada peningkatan kesejahteraan rakyat.

Adapun prinsip otonomi nyata adalah suatu prinsip bahwa untuk menangani urusan pemerintahan dilaksanakan berdasarkan tugas, wewenang, dan kebijakan yang senyatanya telah ada, serta berpotensi untuk tumbuh, hidup, dan berkembang sesuai dengan potensi dan kekhasan daerah. Dengan demikian, isi dan jenis otonomi bagi setiap daerah tidak selalu sama dengan daerah lainnya (otonomi bersifat objektif). Sedangkan yang dimaksud dengan otonomi yang bertanggung jawab adalah otonomi yang dalam penyelenggaraannya harus benar-benar sejalan dengan tujuan dan maksud pemberian 
otonomi yang pada dasarnya untuk memberdayakan daerah termasuk meningkatkan kesejahteraan rakyat yang merupakan bagian utama dari tujuan nasional.

Adapun tujuan otonomi daerah adalah mencapai efektifitas dan efisiensi dalam pelayanan masyarakat sehingga tujuan yang diharapkan dapatmenumbuhkembangkan daerahdalam berbagai bidang ,meningkatkan pelayanan kepada masyarakat, menumbuhkan kemandirian daerah dan meningkatkan daya saing daerah dalam proses pertumbuhan.

\section{b. Pembentukan Daerah}

Sejak penerapan sistem desentralistik di Indonesia kata pembentukan menjadi sesuatu yang tak terpisahkan dalam Undang-Undang Otonomi Daerah. Dalam UndangUndang tersebut daerah diberi kewenangan untuk membentuk atau memisahkan wilayah-wilayahnya menjadi satu atau dua bagian wilayahnya. Banyak daerah menggunakan istilah pembentukan untuk memaknai sebuah pembentukan Daerah otonomi baru dalam suatu wilayahnya.

Pembentukan daerah dapat berupa pemecahan daerah provinsi atau daerah kabupaten/kota untuk menjadi dua atau lebih daerah baru, atau penggabungan bagian daerah dari daerah yang bersanding dalam 1 (satu) daerah provinsi menjadi satu daerah baru. Dalam hubungannya dengan pembentukan daerah/wilayah otonomi, pasal 18 UUD 1945 antara lain menyatakan bahwa pembagian daerah Indonesia atas daerah besar dan daerah kecil dengan bentuk dan susunan pemerintahannya yang ditetapkan oleh Undang-Undang. Daerah Indonesia akan dibagi menjadi daerah provinsi dan daerah provinsi akan dibagi menjadi daerah kabupaten dan daerah kota untuk mendukung pelaksanaan Otonomi Daerah. Peraturan Pemerintah menyebutkan bahwa pembentukan Daerah adalah pemecahan provinsi atau kabupaten/kota menjadi dua daerah atau lebih.Menurut penulis, pembentukan daerah adalah Pemisahan suatu wilayah dari wilayah lain untuk membentuk wilayah baru yang disebabkan oleh meningkatnya kebutuhan masyarakat serta keinginan masyarakat untuk mendapatkan pelayanan yang lebih baik dan merata.

Istilah pemekaran daerah sebenarnya dipakai sebagai upaya memperhalus bahasa yang menyatakan proses perpisahan atau pemecahan satu wilayah untuk membentuk satu unit administrasi lokal baru. Dilihat dari kacamata filosofi harmoni, istilah perpisahan atau perpecahan memiliki makna yang negatif sehingga istilah 
pemekaran daerah dirasa lebih cocok digunakan untuk menggambarkan proses terjadinya daerah-daerah otonom baru pasca reformasi di Indonesia. Jika kita lihat kebelakang, pemekaran daerah begitu gencarnya dilaksanakan sejak zaman reformasi. Hal ini disebabkan oleh adanya anggapan bahwa zaman orde baru yang sentralistis itu sangat tidak adil bagi daerah. Daerah hanya menjadi sapi perahan yang diambil sumber daya alamnya dan hasilnya diserahkan kepemerintah pusat. Tidak ada pembangunan di daerah, pembangunan hanya terpusat di Ibu Kota Negara. Sehingga menimbulkan kesenjangan pembangunan antara pemerintah pusat dan pemerintah daerah.

Secara hukum, syarat-syarat pembentukan suatu wilayah untuk menjadi kabupaten/kota atau provinsi tidak terlalu sulit. Pembentukan harus memenuhi persyaratan dasar dan persyaratan administrasi. Persyaratan dasar meliputi, persyaratan dasar kewilayahan dan persyaratan dasar kapasitas daerah. Persyaratan dasar kewilayahan ini meliputi luas wilayah minimal (berdasarkan pengelompokan pulau atau kepulauan), jumlah penduduk minimal, batas wilayah (dibuktikan dengan titik koordinat pada peta dasar), cakupan wilayah meliputi paling sedikit 5 (lima) kecamatan untuk pembentukan kabupaten, dan 4 (empat) kecamatan untuk pembentukan kota, lokasi calon ibukota, sarana dan prasarana pemerintahan. Namun bukan berarti apabila suatu daerah telah memenuhi persyaratan dasar kewilayahan dan kapasitas daerah maka dengan sendirinya pemekaran wilayah dapat dilakukan.

\section{c. Kedudukan dan Syarat Pembentukan Ibukota Kabupaten Buton Tengah}

Kabupaten Buton Tengah merupakan salah satu kabupaten di Provinsi Sulawesi Tenggara. Ibukotanya berada di Labungakri Kecamatan Lakudo. Buton Tengah merupakan hasil pemekaran dari Kabupaten Buton yang disahkan pada tanggal 24 Juli 2014. Salah satu alasan pemekaran wilayah ini adalah karena permasalahan akses. Seluruh wilayah Buton Tengah tidak berada di Pulau Buotn, sedangkan Ibukota Kabupaten Buton berada di Pasarwajo. Pelayanan dan kontrol membutuhkan biaya dan waktu yang panjang karena harus melewati laut menuju Kota Baubau, lalu dilanjutkan perjalanan darat menuju Pasarwajo di ujung timur Pulau Buton.

Wilayah Kabupaten Buton Tengah terdiri atas 7 kecamatan yang berasal dari sebagian wilayah Kabupaten Buton dengan cakupan wilayah Kecamatan Lakudo, Kecamatan Gu, Kecamatan Sangia wambulu, Kecamatan Mawasangka, Kecamatan Mawasangka Tengah, Kecamatan Mawasangka Timur, dan Kecamatan Talaga Raya. 
Jika dilihat dari sisi aturan, penetapan Labungkari sebagai Ibukota Kabupaten Buton Tengah telah memenuhi syarat sesuai dengan PP Nomor 78 Tahun 2007, yang terdiri dari syarat administrasi, syarat teknis, dan syarat fisik kewilayahan. Syarat administrasi dan syarat fisik kewilayahan Penetapan Labungkri Sebagai Ibukota Kabupaten Buton Tengah dituangkan dalam:

a. Surat Keputusan DPRD Kabupaten Buton Nomor 09/DPRD/2008 tanggal 10 Mei 2008 tentang persetujuan pembentukan Calon Kabupaten Buton Tengah.

b. Keputusan Dewan Perwakilan Rakyat Daerah Kabupaten Buton Nomor 8/DPRD/2010 tanggal 2 Juni 2010 tentang persetujuan lokasi Ibukota Calon Kabupaten Buton Tengah.

c. Keputusan DPRD Kabupaten Buton Nomor 9/DPRD/2010 tanggal 2 Juni 2010 tentang persetujuan pelepasan kecamatan yang menjadi cakupan wilayah calon Kabupten Buton Tengah.

d. Keputusan DPRD Kabupaten Buton Nomor 10/DPRD/2010 tanggal 2 Juni 2010 tentang Persetujuan Pemberian Dana Hibah Untuk penyelenggaraan Pemerintahan Calon Kabupaten Buton tengah.

e. Keputusan DPRD Kabupaten Buton Nomor 11/DPRD/2010 tanggal 2 Juni 2010 Tentang Persetujuan Pemberian Dukungan Dana Untuk Penyelenggaraan Pemilihan Kepala Daerah Pertama Kali Calon Kabupaten Buton Tengah.

f. Keputusan DPRD Kabupaten Buton Nomor 12/DPRD/2010 tentang Persetujuan Penyerahan Kekayaan daerah/sarana Prasarana Kepada Calon Kabupaten Buton Tengah.

g. Keputusan DPRD Nomor 10/DPRD/2014 tanggal 9 Mei 2014 tentang Persetujuan Penetapan Penempatan Ibukota dan Cakupan Wilayah Calon DOB Kabupaten Buton Tengah dan Calon DOB Kabupatern Buton Selatan.

h. Keputusan DPRD kabupaten Buton Nomor 19/DPRD/2013 tanggal 5 Juli 2013 tentang Perubahan calon Ibukota Daerah otonomi Baru Kabupaten Buton tengah.

i. Keputusan Bupati Nomor 148 tahun 2008 tanggal 18 Maret 2008 tentang Persetujuan nama Calon kabupaten Buton tengah.

j. Keputusan Bupati Nomor 149 tahun 2008 tanggal 18 maret 2008 tentang persetujuan Lokasi calon Ibukota kabupaten Buton tengah. 
k. Keputusan Bupati Buton Nomor 150 tahun 2008 tanggal 18 maret 2008 tentang persetujuan Pelepasan Kecamatan yang menjadi cakupan wilayah Calon Kabupaten Buton Tengah.

l. Keputusan Bupati Buton Nomor 150 Tahun 2008 tanggal 18 Maret 2008 tentang Persetujuan pemberian dana Hibah untuk mendukung Penyelenggaraan Pemerintahan Calon kabupaten Buton tengah

m. Keputusan Bupati Buton Nomor 152 tahun 2008 tanggal 18 Maret 2008 tentang Persetujuan Pemberian Dana Untuk Penyelenggaraan Pemilihan Kepala Daerah Pertama Kali Calon Kabupaten Buton tengah.

n. Keputusan Bupati Nomor 153 Tahun 2008 tanggal 18 Maret 2008 tentang Persetujuan Penyerahan Kekayaan daerah/sarana dan Prasarana yang Berada Dalam Cakupan Wilayah Calon Kabupaten Buton tengah.

o. Keputusan Bupati Buton Nomor 415 Tahun 2010 tanggal 7 Juni 2010 tentang Persetujuan pelepasan Kecamatan yang Menjadi Cakupan Wilayah Calon Kabupaten Buton tengah.

p. Keputusan Bupati Buton nomor 416 tahun 2010 tanggal 7 Juni 2010 tentang persetujuan Pemberian Hibah Untuk Mendukung Penyelenggaraan Pemerintahan Calon kabupaten Buton Tengah.

q. Keputusan Bupati Buton Nomor 417 Tahun 2010 tanggal 7 Juni 2010 tentang Persetujuan Pemberian Dukungan Dana Dalam Rangka Membiayai Pemilihan Kepala Daerah Pertama kali Pada Calon Kabupaten Buton Tengah.

r. Keputusan Bupati Buton Nomor 418 tahun 2010 tanggal 7 juni 2010 Tantang persetujuan Penyerahan Kekayaan Daerah/Sarana dan Prasarana yang berada Dalam Cakupan Wilayah Calon Kabupaten Buton tengah.

s. Keputusan DPRD Provinsi Sulawesi Tenggara Nomor: 02 Tahun 2008 tanggal 22 Mei 2008 tentang persetujuan Pembentukan Daerah Otonomi Kabupaten Buton tengah.

t. Keputusan DPRD Provinsi Sulawesi Tenggara Nomor: 7 Tahun 2010 Tanggal 16 Juni 2010 tentang Penyempurnaan Atas Keputusan DPRD Provinsi Sulawesi Tenggara Nomor 2 Tahun 2008 tentang Persetujuan Pembentukan Daerah Otonomi Baru Kabupaten Buton tengah.

u. Surat Gubernur Sulawesi Tenggara Nomor 136/3056 tanggal 6 juni 2008, perihal usul Pembentukan Daerah Otonomi Baru. 
Syarat teknis yaitu hasil kajian daerah yang salah satunya yaitu kemampuan ekonomi. Masyarakat Buton tengah Masyarakat Buton Tengah berprofesi sebagai petani, nelayan, pelaut, pedagang, dan sebagian kecil bekerja di sektor pertambangan. Wilayah Kabupaten Buton Tengah sangat berpotensi untuk dikembangkan perkebunan jagung, singkong, ubi jalar, dan kacang hijau. Perkebunan jagung di Kecamatan Gu seluas 2.679 Ha dengan total produksi 537 ton jagung. Di Kecamatan Gu juga memiliki luas area pertanian singkong dengan luas area 2.679 Ha dengan total produksi 11.258 ton, perkebunan kapuk 56,35 Ha dengan total produksi mencapai 480 ton, dan perkebunan kakao seluas 32 Ha dengan total produksi mencapai 390 ton.

Potensi laut yang dapat dimanfaatkan yaitu perikanan dan budidaya rumput laut yang produksinya mencapai 13.966,34 ton. Kecamatan Talaga Raya juga menyimpan kekayaan mineral berupa tambang nikel. Dari sektor pariwisata, beberapa objek wisata baik wisata alam, sejarah maupun budaya menjadi daya tarik tersendiri. Seperti beberapa benteng bekas peninggalan kesultanan buton, adat dan tradisi masyarakat Gulamasta.

\section{METODE PENELITIAN}

Teknik pengumpulan data yang digunakan dalam penelitian ini adalah : Wawancara, yakni dilakukan wawancara langsung dengan responden yang diharapkan mampu memberikan masukan dan penjelasan mengenai masalah tersebut dengan baik dan benar.

Kepustakaan, yakni pengumpulan bahan dengan menelaah peraturan perundangundangan yang berhubungan dengan masalah tersebut, atau literatur lain yang berhubungan dengan masalah tersebut.

Jenis dan sumber data yang digunakan dalam penelitian ini adalah sebagai berikut:

1. Bahan hukum primer yakni bahan hukum yang diperoleh dari responden berdasarkan hasil wawancara.

2. Bahan hukum sekunder yakni bahan hukum yang diperoleh melalui studi kepustakaan, referensi-referensi hukum, peraturan perundang-undangan dan dokumen hukum.

3. Bahan hukum tersier yakni bahan hukum pelengkap,yaitu artikel yang berkaitan dengan penelitian ini. 
Teknik analisa penelitian yang digunakan adalah teknik kualitatif yang informasinya digali melalui wawancara mendalam serta informasi yang diperoleh melalui penelusuran kepustakaan, baik dari peraturan perundang-undangan, dokumen yang berkaitan dengan penulisan skripsi ini sehingga apa yang menjadi pertanyaan dalam penelitian ini terjawab dengan maksimal.

\section{PEMBAHASAN}

a. Analisis Sesuai atau Tidaknya Syarat-Syarat Pembentukan Daerah Otonomi Baru Kabupaten Buton Tengah Berdasarkan Peraturan PerundangUndangan

Dalam skripsi ini hanya akan dijelaskan gambaran umum Kecamatan lakudo dan Kecamatan Mawasangka yang merupakan wilayah yang diusulkan untuk calon Ibukota Kabupaten Buton Tengah. Dengan menganalisis kondisi fisik wilayah berupa konfigurasi wilayah, aksesibilitas dan ketersediaan fasilitas.

Ketersediaan fasilitas dasar sebagai pendukung pelaksanaan pemerintahan dan perekonomian, terdiri dari Gedung Pembantu Bupati Wilayah Gulamas Mawasangka, fasilitas pemerintahan kecamatan, lembaga perbankan (BRI) Kantor Pos dan pasar.

Secara lebih khusus, pembentukan daerah diatur dalam UU No. 23 Tahun 2014 tentang Pemerintahan Daerah. Dalam Undang-Undang tersebut dijelaskan bahwa pembentukan dapat berupa pemekaran daerah dan penggabungan daerah. Pemekaran daerah dilakukan melalui tahapan daerah persiapan Kabupaten/Kota. Tahapan daerah persiapan Kabupaten/kota ini salah satu syarat yang harus dipenuhi adalah penentuan calon Ibukota Kabupaten/Kota.

Awalnya Wamengkoli yang telah memenuhi syarat sesuai dengan PP No. 78 Tahun 2007, dalam perkembangannya kemudian muncul nama Mawasangka yang kalau dikaji juga memenuhi syarat. Tapi satu hal yang menjadi pertimbangan bahwa pemekaran kabupaten itu semangatnya bukan hanya dilihat dari memenuhi atau tidaknya syarat yang ditetapkan UU tapi bagaimana ada sebuah konsensus bersama ditingkat masyarakat dicakupan itu. Labungkari awalnya muncul dari konsensus itu, bahwa polemik pemekaran Buton Tengah itu ada pada letak ibukota dan berbagai pertimbangan bahwa kalau di Wamengkoli masih sama saja, kesulitan yang dihadapi saudara-saudara kita dari Mawasangka, Talaga, Mawasangka Tengah, Mawasangka Timur terkait dengan akses 
pemerintahan juga Wamenkoli masih sangat dekat dengan Kota Baubau. Namun kalau di Mawasangka, ada juga komplain dari Lakudo, Lombe, dan Sangia Wambulu bahwa masih terlalu jauh juga. Sehingga disepakatilah oleh perwakilan elemen-elemen yang ada dimana kita mencari titk temu yaitu di tengah-tengah maka disepakatilah Labungkari.

Padahal jika dilihat dari pemaparan Nur Alam dalam Rapat Dengar Pendapat terbuka pada 30 Januari 2014 di Gedung DPR RI Senayan Jakarta tentang kondisi objektif terkini terkait Buton Tengah mengenai syarat teknis yang ditampilkan dengan data scoring bahwa angka tertinggi adalah Kecamatan Mawasangka dengan nilai scoring 26 sedangkan Labungkari.

Berdasarkan hasil kajian akademisyang dilakukan Universitas Haluoleo bahwa analisis skalogram menunujukkan bahwa Kecamatan $\mathrm{Gu}$ peringkat 1(satu) dan Kecamatan Lakudo peringkat 2 (dua) yang memiliki jumlah fasilitas dan pelayanan, sedangkan Kecamatan Mawasangka peringkat 3 (tiga) kemudian Kecamatan Mawasangka Tengah peringkat 4 (empat), Kecamatan Mawasangka Timur peringkat 5 (lima), Kecamatan Sangiawambulu peringkat 6 (enam) dan Talaga Raya peringkat 7 (tujuh). Letak lokasi Labungkari di Kecamatan Gu dan Kecamatan Lakudo sehingga kriteria Labungkari sebagai pusat pertumbuhan wilayah memiliki jumlah dan jenis fasilitas terbanyak untuk memenuhi berbagai kebutuhan penduduk di Kabupaten Buton tengah.Dengan adanya kajian akademis itu sehingga syarat formal yang sesuai dengan PP No. 78 Tahun 2007 itu sudah terpenuhi, ada kajian akademisnya, akta hibah, tapal batas kawasan ibukota dan kriteria-kriteria lainnya khusus kawasan ibukotanya sementara labungkari tetap dalam kawasan Kecamatan Lakudo.

\section{b. Kelemahan dan Kelebihan ditetapkanya Labungkari sebagai Ibukota kabupaten Buton Tengah}

Kelebihan di tetapkanya Labungkari sebagai Ibukota Kabupaten Buton Tengah yaitu, walaupun wilayahnya tidak berada persis ditengah-tengah namun dianggap sebagai titik tengah karena dari Wamengkoli ke labungkari jaraknya $28 \mathrm{Km}$ kemudian dari mawasangka ke Labungkari jaraknya $34 \mathrm{Km}$, jadi selisihnya sekitar $8 \mathrm{Km}$. Selanjutnya kawasan yang menjadi cakupan Labungkari sebagai kawasan ibukota itu, hutannya dalam penguasaan Negara sehingga sangat memudahkan pemerintah untuk melakukan ekspansi penataan karena jika wilayah tersebut masih dikuasai masyarakat 
pemerintah harus membebaskan lahannya yang membutuhkan ekonomi besar. Jika wilayah tersebut juga masuk dalam kategori hutan lindung itu juga menjadi masalah karena pemerintah harus meminta izin dengan prosedur yang panjang di Kementerian Kehutanan. Dari sisi ekonomi penempatan ibukota Kabupaten Buton Tengah sudah bagus, karena Labungkari merupakan poros utama antara Mawasangka, Wamengkoli, Raha dan sekitarnya.

Kelemahan ditetapkannya Labungkari sebagai ibukota Kabupaten Buton Tengah yaitu, akses pelabuhan di labungkari itu hampir tidak ada. Sementara ibukota kabupaten yang sangat bagus apalagi wilayah Buton Tengah ini masih dalam kawasam maritim itu sebenarnya harus dekat dengan kawasan laut. Selanjutnya luas lahan yang dihibahkan masyarakat untuk kawasan ibukota lebih sedikit dibandingkan dengan luas tanah yang dihibahkan di dua wilayah yang juga diusulkan sebelumnya sebagai calon ibukota Kabupaten Buton Tengah. Kemudian kelemahan lainnya yaitu kawasan yang menjadi ibukota Kabupaten Buton Tengah ini merupakan kawasan yang masih kosong.

\section{E. KESIMPULAN}

Berdasarkan penelitian yang telah dilakukan sesuai dengan permasalahan yang diteliti maka pada bagian ini dirumuskan kesimpulan, yaitu :

1. Penetapan Labungkari sebagai ibukota Kabupaten Buton Tengah tidak layak karena pada awal pemilihannya hanya berdasarkan konsensus antar perwakilan dari elemen-elemen masyarakat agar tidak terjadi tarik menarik antara dua kecamatan yaitu Kecamatan Mawasangka dan Kecamatan Lakudo yang sebelumnya telah diusulkan menjadi calon ibukota Kabupaten Buton Tengah yang dapat menghambat pemekaran itu sendiri.

2. Kelemahan atas penetapan Labungkari sebagai ibukota Kabupaten Buton Tengah ini yang berdampak khususnya dari sisi ekonomi, meskipun Labungkari ini merupakan poros utama antara mawasangka, Wamengkoli dan Raha namun kawasan ini sangat jauh dengan kawasan laut sehingga menyebabkan akses pelabuhan juga sangat jauh. 


\section{DAFTAR PUSTAKA}

\section{A. Buku}

Kaloh, J. 2007. Mencari Bentuk Otonomi Daerah. Rineka Cipta:Jakarta

Kasmawati, Andi. 2010. Implikasi Hukum Kebijakan Desentralisasi.Rayhan Intermedia: Makassar

Manan, Bagir.2005.Menyongsong Fajar Otonomi Daerah.Pusat Studi Hukum UII: Yogyakarta

Muchlis, Hamdi. 2008. Naskah Akademik tentang Pembentukan dan Penghapusan Daerah. BPHN DEPKUMHAM RI: Jakarta

Muslimin,Amrah.1986.Aspek-Aspek Hukum Otonomi Daerah.Alumni: Bandung

Ratnawati,Tri.2009.Pemekaran Daerah: Politik Lokal dan Beberapa Isu Terseleksi.Pustaka Pelajar:Yogyakarta

Soejito,Irawan.1990.Hubungan Pemerintah Pusat dan Pemerintah Daerah.Rineka Cipta:Jakarta

Soerjono,Soekanto.1986.Pengantar Penelitian Hukum.UI Press:Jakarta

Sunarno,Siswanto.2005.Hukum Pemerintahan Daerah.Sinar Grafika:Jakarta

Widjaja, H.A.W.2005.Penyelenggaraan Otonomi Daerah Di Indonesia.PT Raja Grafindo Persada: Jakarta

B. Peraturan Perundang-undangan

- Undang-Undang Negara Republik Indonesia 1945

- Undang Undang Nomor 23 Tahun 2014 tentang Pemerintahan Daerah

- Undang-Undang Nomor 15 Tahun 2014 Tentang Pembentukan Buton Tengah

- PP Nomor 78 Tahun 2007 tentang Tata Cara Pembentukan, Penghapusan dan Penggabungan Daerah. 